\title{
ASSESSMENT OF THE STATE OF THE EPIDEMIOLOGICAL SITUATION OF LYMPHOGRANULOMATOSIS IN DIFFERENT REGIONS OF UKRAINE AS AN IMPORTANT COMPONENT IN THE DEVELOPMENT OF DIRECTIONS FOR IMPROVEMENT OF PHARMACEUTICAL SUPPORT OF ONCOHEMATOLOGICAL PATIENTS
}

\author{
H. Panfilova, M. Matushchak, L. Kostyshyn, O. Skrynchuk, Zyro Dominik, O. Tsurikova
}

\begin{abstract}
The aim: to conduct epidemiological studies of the morbidity and mortality of the population from lymphogranulomatosis in the regions of the country in dynamics over the years and to identify regions of the country that require special attention in the process of early detection of this pathology and effective pharmaceutical provision of patients.

Materials and methods. The object of the research was the official data of the National Cancer Registry from $2012-$ 2019. The research used both general theoretical (historical, analytical and comparative, systemic, graphic, logical, hypothetical-deductive) and applied (mathematical-statistical, epidemiological) methods of research.

Results. It has been established that the average morbidity and mortality rates of the population from lymphogranulomatosis in Ukraine exceed similar world data (morbidity/mortality - 2.3/0.4 for men and 1.9/0.3 for women per 100 thousand population). Thus, the calculated morbidity rates were 2.5, and the mortality rate was 0.7 per 100 thousand population. It has been proved that morbidity and mortality rates by region varied in a significant range of values, namely, morbidity - from 1.8 (Transcarpathian region) to 3.0 (Kyiv), and mortality - from 0.4 (Cherkasy region) to 0.9 (Ivano-Frankivsk, Kyiv, Chernivtsi regions) per 100 thousand population. According to the results of the grouping, most regions of the country (14 regions and Kyiv city) were assigned to the group of extremely unfavourable (group D) development of the epidemiological situation in terms of lymphogranulomatosis. Ivano-Frankivsk region was attributed to the group of unfavourable (group $C$ ) development of this process. Four (Transcarpathian, Vinnytsia, Zhytomyr and Kherson) regions were included in the group of favourable (group A) development of the epidemiological situation. The group of relatively favourable (group B) - three areas. These are the Volyn, Chernigov and Cherkasy regions.

Conclusions. The presence of an extremely unfavourable (14 regions and Kyiv city) and unfavourable (Ivano-Frankivsk region) onco-epidemiological situation necessitates the development and implementation of regional programs for the early detection of lymphogranulomatosis and the provision of patients with affordable and effective anticancer drugs in accordance with the existing resource provision at the level of regions and local communities
\end{abstract}

Keywords: epidemiology of lymphogranulomatosis, epidemiology of Hodgkin's disease, morbidity, lymphomas, Hodgkin's lymphoma, lymphogranulomatosis, oncohematology, oncoepidemiology, mortality, Hodgkin's disease

Copyright (C) 2020, H. Panfilova, M. Matushchak, L. Kostyshyn, O. Skrynchuk, Zyro Dominik, O. Tsurikova.

This is an open access article under the CC BY license (http://creativecommons.org/licenses/by/4.0).

\section{Introduction}

Despite the significant achievements of modern medicine and pharmacy, the problem of effective treatment of patients with cancer remains unresolved [1, 2]. A special place in modern oncology is occupied by those pathologies that affect children, people of working age, and also require the involvement of considerable resources for chemotherapy and further rehabilitation of patients [3, 4]. These pathologies also include lymphogranulomatosis (LG).

LG appears as a neoplasm of the human lymphatic system, which in the early stages of its development is almost asymptomatic [5, 6]. In the structure of the total morbidity and mortality of the population on oncological pathologies, the proportion (\%) of patients with LG is approximately $0.5-0.7 \%[7,8]$. In countries with relatively high levels of socio-economic development, LG morbidity and mortality are 2.3 and 0.4 for males and 1.9 and 0.3 for females, respectively [2]. Morbidity and mortality data in countries with relatively low levels of socioeconomic development are 0.8 and 0.4 for men and 0.5 and 0.3 for women $[9,10]$. Despite the fact that the incidence of LG does not exceed the world values of 2-4 cases per 100 thousand of population, the problem of early detection and effective treatment of this oncological pathology is of great socio-economic importance $[8,11]$. First, in the age group of oncohematological patients from 15 to 34 years, this diagnosis is given to every sixth patient, and this is known to be the most socially active people in society $[12,13]$. Second, LG requires longterm and high-cost treatment, and in some groups of patients also autologous stem cell transplantation procedures $[14,15]$. In $17.0 \%-20.0 \%$ of patients in almost all age groups, despite the received chemotherapy, there is a progressive development of this disease $[12,13]$. In the future, such patients require the use of anticancer drugs of the second line of chemotherapy $[16,17]$. Some studies present data on the dependence of epidemiological indicators of LG on the place of birth $[1,16]$, as well as the place of permanent residence [18, 19]. According to the literature, the effectiveness of treatment of patients with LG is currently being considered in the direction of 
the introduction of rational, from a clinical and economic point of view of chemotherapy regimens [20, 21]. The presence of such high-value drugs in such schemes [22, 23] against the background of limited funding of the public health sector, may call into question the availability of effective medical and pharmaceutical care to LG patients [24, 25]. Under these conditions, the issue of effective allocation of limited resources allocated for the purchase of anticancer drugs for the treatment of patients with LG in accordance with the state of the epidemiological situation in different regions of the country is relevant.
The aim of the research is to conduct epidemiological studies of morbidity and mortality from lymphogranulomatosis in the regions of the country over the years and to identify areas that require special attention to early detection of this pathology and effective pharmaceutical supply of patients.

\section{Research planning (methodology)}

In order to solve the goal of the study, we developed a plan of applied research, which contained six stages. The content and procedure for implementing the work in the outlined stages are given in Table 1.

Table 1

Characteristics of the content and procedure for applied research

\begin{tabular}{|c|c|}
\hline The name of the stage & Characteristics of the content and procedure \\
\hline \multicolumn{2}{|c|}{ Preliminary data processing and scientific evaluation of previously conducted research in this area } \\
\hline The first stage & $\begin{array}{l}\text { Analysis of data from the special literature on a range of issues related to the organization } \\
\text { of rational models of providing patients with LG with anticancer drugs, as well as assess- } \\
\text { ment of the epidemiological situation in different countries around the world on cancer of } \\
\text { the human lymphoid system. Scientific evaluation of the results of epidemiological studies } \\
\text { conducted in Ukraine on LG over the past ten years. }\end{array}$ \\
\hline \multicolumn{2}{|r|}{ Defining the purpose of the research, developing tasks and defining research methods } \\
\hline The second stage & $\begin{array}{l}\text { Analyzing the problem under consideration, as well as evaluating the applied nature of } \\
\text { research, we formulated the purpose and developed the main stages of work (copying, } \\
\text { evaluation, import, research, data analysis, development of areas of prospective research). } \\
\text { At this stage, we have outlined research methods, which were conventionally divided into } \\
\text { general theoretical and applied. }\end{array}$ \\
\hline \multicolumn{2}{|c|}{ Collection, preliminary analysis and assessment of the reliability of primary information } \\
\hline The third stage & $\begin{array}{l}\text { According to the analysis of the National Cancer Registry (NCR) in the Bulletin No. } 21 \\
\text { [26] the data on morbidity and mortality of the population of Ukraine from LG for 2012- } \\
2019 \text { were copied in accordance with the administrative-territorial division of the country } \\
\text { [27]. Thus, it was established that out of } 27 \text { administrative-territorial units of the country in } \\
\text { the NCR since 2014, there is no information on Luhansk and Donetsk regions, Sevastopol } \\
\text { and the Autonomous Republic (AR) of Crimea. In addition, from } 2012 \text { to } 2018 \text {, all indica- } \\
\text { tors are presented with the status "updated", and for } 2019 \text { - "operational" data was availa- } \\
\text { ble. After verification, all indicators were imported into the statistical analysis database } \\
\text { Statistica (version 12.0, StatSoft, Tulsa, USA) for further processing and analysis. }\end{array}$ \\
\hline \multicolumn{2}{|c|}{$\begin{array}{l}\text { Ranking of regions of the country and levels of risks according to the analysis of ratios between morbidity and mor- } \\
\text { tality of the population from LG }\end{array}$} \\
\hline The fourth stage & $\begin{array}{l}\text { According to the calculations of the average chronological indicators of morbidity and } \\
\text { mortality of the population from LG for } 2012-2019 \text {, all regions of the country were ranked } \\
\text { by risk groups (group I - low risk, group II - medium risk, group III - relatively high risk, } \\
\text { group IV - high risk). A p-value }<0.05 \text { was considered statistically significant. }\end{array}$ \\
\hline \multicolumn{2}{|r|}{ Assessment of limitations in the use and interpretation of research results } \\
\hline The fifth stage & $\begin{array}{l}\text { Critical analysis of the obtained research and modelling of the process of their use in the } \\
\text { future allowed to determine the objective limitations on their practical use. In addition, } \\
\text { according to this reflection, the directions of further promising research in this direction } \\
\text { were formulated. }\end{array}$ \\
\hline \multicolumn{2}{|c|}{ Formulation of the main conclusions based on the results of the analysis and directions of prospective research } \\
\hline The sixth stage & $\begin{array}{l}\text { Outlining the findings of research. Understanding the need to implement a regional ap- } \\
\text { proach to solving a number of problems, especially those related to socially painful issues. } \\
\text { The introduction of scientifically sound approaches in the organization of medical and } \\
\text { pharmaceutical care will form a stable positive profile of state institutions in society, the } \\
\text { main task of which is the effective implementation of appropriate state guarantees for } \\
\text { vulnerable groups and the chronically ill. }\end{array}$ \\
\hline
\end{tabular}

\section{Materials and methods}

The object of research was the data on morbidity and mortality of the population of Ukraine from LG for 2012-2019 in terms of regions of the country. The studies used epidemiological indicators that are standardized in the NCR according to the age structure of the population of Ukraine (2000). The standardization of these indicators allows them to be freely used for comparison with each other in different regions of the country [26]. For all administrative-territorial units of the country and in 
Ukraine as a whole, chronological mean values were determined $\left(\overline{\mathrm{U}}=\left(\mathrm{x}_{1: 2}\right)+\mathrm{x}_{2}+\ldots+\mathrm{x}_{\mathrm{n}-1}+\left(\mathrm{x}_{\mathrm{n}: 2}\right)\right)$ : $\mathrm{n}-1_{1}$ incidence $\left(\mathrm{X}_{\text {av.morb. }}\right)$ and mortality $\left(\mathrm{X}_{\mathrm{av} . \text { mort. }}\right)$ population from LG. It is known that chronological averages are used in time series to determine the average level of the moment series [28]. Subsequently, taking into account the rate of variation $\left(\mathrm{R}=\mathrm{X}_{\max }-\mathrm{X}_{\min }\right)$ in terms of morbidity and mortality from $\mathrm{LG}$ and a given number $(\mathrm{N}=4)$ of risk groups, all regions were divided into four groups at equal intervals:

Group I - low risk of morbidity and mortality;

Group II - medium risk;

Group III - relatively high risk;

Group IV - high risk.

Based on the results of the analysis of these indicators by regions of the country by groups of risk of development and mortality from LG, an appropriate matrix for assessing the state of development of the epidemiological situation on the specified oncological pathology was built.

In our research we used both general theoretical methods (historical, comparative, graphic, graphic, hypothetical-deductive, etc.) and applied methods used in organizational and economic, marketing research in pharmacy. In addition, epidemiological and mathematical-statistical research methods were used.

\section{Research results}

The analysis of indicators characterizing the state of development of the epidemiological situation in Ukraine on lymphogranulomatosis was carried out according to the archives and information presented in the NCR open access (Bulletins No. 17-21) during 20122019 for 23 administrative-territorial units of the country (22 regions and Kyiv). According to the results of the research, it was established that the average morbidity rate $\left(\mathrm{X}_{\mathrm{av} \text {.morb. }}\right)$ in Ukraine was 2.52 , and the mortality rate $\left(\mathrm{X}_{\text {av.mort. }}\right)$ was 0.71 per 100 thousand population. That is, Ukrainian indicators exceed world data (2.3 and 0.4 for men and 1.9 and 0.3 for women, respectively) [2]. By regions of the country, the incidence ranged from 1.8 (Zakarpattia region) to 3.0 (Kyiv), and mortality from 0.4 (Cherkasy region) to 0.9 (Ivano-Frankivsk, Zaporizhia, Chernivtsi region) per 100 thousand population. The results of calculations by regions of the country are presented in Table 2.

Table 2

Distribution of regions of the country by indicators $X_{\text {av. morb }}$ and $X_{\text {av.mort. }}$ of $L G$

\begin{tabular}{|c|c|c|c|c|c|c|c|}
\hline No. & Region & $\begin{array}{c}\mathrm{X}_{\text {av.morb. }} / \mathrm{X} \\
\text { av.mort. }\end{array}$ & Groups & No. & Region & $\begin{array}{c}\mathrm{X}_{\mathrm{av.morb} .} / \mathrm{X}_{\mathrm{av}} \\
\text { mort. }\end{array}$ & Groups \\
\hline 1 & Ukraine & $\begin{array}{c}2.53 \pm 0.29 / \\
0.69 \pm 0.14\end{array}$ & III/III & 15 & Mykolayiv & $\begin{array}{c}2.58 \pm 0.30 / \\
0.81 \pm 0.08\end{array}$ & III/IV \\
\hline 2 & Crimea* & - & - & 16 & Odesa & $\begin{array}{c}2.91 \pm 0.33 / \\
0.83 \pm 0.08\end{array}$ & IV/IV \\
\hline 3 & Vinnytsia & $\begin{array}{c}2.29 \pm 0.26 / \\
0.59 \pm 0.06\end{array}$ & $\mathrm{II} / \mathrm{II}$ & 17 & Poltava & $\begin{array}{c}2.69 \pm 0.31 / \\
0.67 \pm 0.07\end{array}$ & IV/III \\
\hline 4 & Volyn & $\begin{array}{c}2.43 \pm 0.28 / \\
0.48 \pm 0.05\end{array}$ & III/I & 18 & Rivne & $\begin{array}{c}2.48 \pm 0.29 / \\
0.72 \pm 0.07\end{array}$ & III/III \\
\hline 5 & Dnipropetrovsk & $\begin{array}{c}2.79 \pm 0.32 / \\
0.81 \pm 0.08\end{array}$ & IV/IV & 19 & Sumy & $\begin{array}{c}2.48 \pm 0.29 / \\
0.68 \pm 0.07\end{array}$ & III/III \\
\hline 6 & Donetsk* & - & - & 20 & Ternopil & $\begin{array}{c}2.42 \pm 0.28 / \\
0.79 \pm 0.08\end{array}$ & III/IV \\
\hline 7 & Zhytomyr & $\begin{array}{c}2.12 \pm 0.24 / \\
0.57 \pm 0.06\end{array}$ & $\mathrm{I} / \mathrm{II}$ & 21 & Kharkiv & $\begin{array}{l}2.62 \pm 0.30 / \\
0.69 \pm 0.07\end{array}$ & III/IV \\
\hline 8 & Transcarpathian & $\begin{array}{l}1.78 \pm 0.20 / \\
0.58 \pm 0.06\end{array}$ & $\mathrm{I} / \mathrm{II}$ & 22 & Kherson & $\begin{array}{c}2.31 \pm 0.27 / \\
0.52 \pm 0.05\end{array}$ & II/I \\
\hline 9 & Zaporizhia & $\begin{array}{c}2.77 \pm 0.32 / \\
0.89 \pm 0.09\end{array}$ & IV/IV & 23 & Khmelnytsky & $\begin{array}{c}2.92 \pm 0.34 / \\
0.62 \pm 0.06\end{array}$ & IV/III \\
\hline 10 & Ivano-Frankivsk & $\begin{array}{c}2.22 \pm 0.26 / \\
0.92 \pm 0.09\end{array}$ & II/IV & 24 & Cherkasy & $\begin{array}{l}2.59 \pm 0.30 / \\
0.42 \pm 0.04\end{array}$ & III/I \\
\hline 11 & Kyiv & $\begin{array}{c}2.89 \pm 0.33 / \\
0.61 \pm 0.06\end{array}$ & IV/III & 25 & Chernivtsi & $\begin{array}{c}2.37 \pm 0.27 / \\
0.87 \pm 0.09\end{array}$ & III/IV \\
\hline 12 & Kirovograd & $\begin{array}{c}2.73 \pm 0.31 / \\
0.81 \pm 0.08\end{array}$ & IV/IV & 26 & Chernihiv & $\begin{array}{c}2.48 \pm 0.29 / \\
0.57 \pm 0.06\end{array}$ & III/II \\
\hline 13 & Luhansk* & - & - & 27 & Kyiv & $\begin{array}{c}3.01 \pm 0.35 / \\
0.72 \pm 0.07\end{array}$ & IV/IV \\
\hline 14 & Lviv & $\begin{array}{l}2.40 \pm 0.28 / \\
0.61 \pm 0.06\end{array}$ & III/III & 28 & Sevastopol* & - & - \\
\hline
\end{tabular}

Note: *-a priori were excluded from the analysis for lack of data in the NCR since 2014

As you can see, according to $\mathrm{X}_{\mathrm{av} \text {.morb. }}$ only two regions were included in the first group of low risk. These are Zhytomyr and Zakarpattia.

To the II group of medium risk 3 regions (Vinnytsia, Ivano-Frankivsk and Kherson regions), to the III group of relatively high risk 10 regions, and to the IV group of high risk 8 regions of the country were included. By share (\%) of regions (23 regions) by risk groups for LG incidence were distributed as follows: group I of low risk $-8.7 \%$; group II of medium risk $13.0 \%$; group III of relatively high risk $-43.5 \%$; group IV of high risk $-34.8 \%$. 
In accordance with the calculated indicators $\mathrm{X}_{\mathrm{av} \text { mort. }}$ of the regions were grouped by us as follows. Group I of low risk included 3 regions (Cherkasy, Volyn and Kherson regions), which is $13.0 \%$, group II of medium risk - 4 regions (Vinnytsia, Zhytomyr, Zakarpattia and Chernihiv regions), which is $17.4 \%$. from the total number of administrative-territorial units that participated in the research. Group III of relatively high risk consisted of 6 regions, which was $26.1 \%$, and group IV of high risk included 10 regions or $43.5 \%$. According to the average values of $\mathrm{X}_{\mathrm{av} \text {.morb. data and }}$ $\mathrm{X}_{\text {av.mort. }}$ Ukraine as country became part of group III, both in terms of morbidity and analysis of LG mortality data.

In order to assess the state of the epidemiological situation, as well as the possibility of providing effective medical and pharmaceutical care to patients with LG, we have built an appropriate matrix. All regions were ranked into four conditional groups, namely group A included those regions in which the state of development of the epidemiological situation is, in our opinion, favourable. To group $\mathrm{B}$ - relatively favourable, to $\mathrm{C}$ - unfavourable and to group $\mathrm{D}$ - extremely unfavourable. The affiliation of a region to groups was determined by analyzing the distribution of administrative-territorial units by risk groups in accordance with their values $\mathrm{X}_{\mathrm{av} \text {.morb. }}$ and $\mathrm{X}_{\mathrm{av} \text {.mort. }}$ (tab. 3). It is clear that the presence of low and medium risk in the region in terms of morbidity and mortality (combinations I/I; I/II; II/I; II/II) allows us to classify it as group A (favourable state of the epidemiological situation). Group (B) of relatively favourable condition in the epidemiology of LG included those regions in which against the background of relatively high values of $\mathrm{X}_{\text {av.morb. }}$ (III-relatively high and IV-high risk in terms of morbidity) we observed a low mortality rate from patients with LG (I-low and II-medium low risk in terms of $\mathrm{X}_{\text {av.morb. This }}$ decision was due to the fact that in the study we were able not only to assess the development of the epidemiological situation, but also to take into account the effectiveness of these medical and hematological patients in medical and pharmaceutical care. An important indicative indicator used for this purpose in oncology is the level of 5-year survival of patients $[29,30]$. According to static data, in economically developed countries, this figure is on average $96.0 \%[1,12]$, and in Ukraine it ranges from 72.0 to $75.0 \%[31,32]$. In general, it can be argued that the incidence of LG depends on a wide range of external and internal factors, the influence of which on the development of the pathological process has not been fully studied $[15,33]$. In contrast to morbidity, the mortality rate of cancer patients largely depends on the state of the organization of providing them with effective medical care and appropriate pharmaceutical support. Therefore, it is the mortality rates in our studies that dominated the incidence data in the process of assigning a region to the appropriate groups (A, B, C, D). Therefore, group C with an unfavourable state of development of the studied process included those regions that are on the background of low or medium risk in terms of $\mathrm{X}_{\mathrm{av} \text {.morb. }}$ had a relatively high and high risk in terms of $\mathrm{X}_{\text {av.mort. }}$ Thus, group $\mathrm{C}$ contained a combination of: IV/II; I/III; II/III; I/IV; II/IV. Thus, group A out of 15 (100.0\%) positions in the matrix has four, of which only one remained unfilled $\left(\mathrm{X}_{\text {av.morb. }} / \mathrm{X}_{\text {av.morb. }}-\mathrm{I} / \mathrm{I}\right)$. Group B (relatively favourable state of the epidemiological situation) has three positions, of which one is also unfilled $\left(\mathrm{X}_{\mathrm{av} . m o r b} / \mathrm{X}_{\mathrm{av} . \text { mort. }}-\mathrm{IV} / \mathrm{I}\right)$. Group $\mathrm{C}$ (unfavourable) has the largest number of positions. This group included only one region with a combination of indicators II/IV (Ivano-Frankivsk region). We included

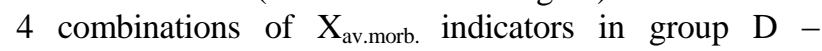
extremely unfavourable prognosis and $\mathrm{X}_{\text {av.mort. }}$ and they were all filled in a constructed matrix.

Let us dwell in more detail on the analysis of the constructed matrix and its composition (Table 4).

Table 3

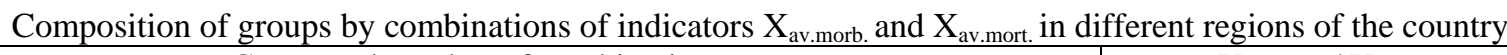

\begin{tabular}{|c|c|}
\hline Group and number of combinations & $\mathrm{X}_{\text {av.morb. }} / \mathrm{X}_{\text {av.mort. }}$ \\
\hline $\begin{array}{l}\text { A - favourable state of development of the oncoepidemiological situation } \\
\text { (4 combinations) }\end{array}$ & I/I; I/II; II/I;II/I \\
\hline $\begin{array}{l}\text { B - relatively favourable state of development of the oncoepidemiological situation } \\
\text { (3 combinations) }\end{array}$ & III/I; III/II; IV/I \\
\hline $\begin{array}{l}\text { C - unfavourable state of development of oncoepidemiological situation } \\
\text { (5 combinations) }\end{array}$ & IV/II; I/III; II/III; I/IV; II/IV; \\
\hline $\begin{array}{l}\text { D - extremely unfavorable state of development of oncoepidemiological situation } \\
\text { (4 combinations) }\end{array}$ & III/III; IV/III; IV/IV; III/IV \\
\hline
\end{tabular}

Table 4

Matrix for assessing the development of the epidemiological situation according to LG in different regions of the country

\begin{tabular}{|c|c|c|c|c|}
\hline $\begin{array}{l}\mathrm{X}_{\text {av.morb }} / \\
\mathrm{X}_{\text {av.mort. }}\end{array}$ & I group of low risk & $\begin{array}{l}\text { II group of } \\
\text { medium risk }\end{array}$ & $\begin{array}{c}\text { III group of relatively high } \\
\text { risk }\end{array}$ & IV group of high risk \\
\hline Group I & A $(0$ regions $)$ & $\begin{array}{l}\text { A (1 region): } \\
\text { Kherson }\end{array}$ & $\begin{array}{c}\text { B (2 regions): Volyn, } \\
\text { Cherkasy }\end{array}$ & B (0 regions) \\
\hline $\begin{array}{c}\text { Group } \\
\text { II }\end{array}$ & $\begin{array}{l}\text { A (2 regions): Zhyto- } \\
\text { myr, Transcarpathian }\end{array}$ & $\begin{array}{l}\text { A (1 region): } \\
\text { Vinnytsia }\end{array}$ & B (1 region): Chernihiv & $\mathbf{C}$ (0 regions) \\
\hline $\begin{array}{c}\text { Group } \\
\text { III }\end{array}$ & $\mathbf{C}(0$ regions $)$ & $\mathbf{C}$ (0 regions) & $\begin{array}{l}\text { D (5 regions): Lviv, Rivne, } \\
\text { Sumy, Ternopil, Kharkiv }\end{array}$ & $\begin{array}{c}\text { D (3 regions): Kyiv, Poltava, } \\
\text { Khmelnytsky }\end{array}$ \\
\hline $\begin{array}{l}\text { Group } \\
\text { IV }\end{array}$ & $\mathbf{C}$ (0 regions) & $\begin{array}{c}\text { C }(1 \text { region }): \\
\text { Ivano-Frankivsk }\end{array}$ & $\begin{array}{l}\text { D }(2 \text { regions }): \\
\text { Mykolayivska, Chernivtsi }\end{array}$ & $\begin{array}{c}\text { D (5 regions): Dnipropetrovsk, } \\
\text { Zaporizhia Kirovograd, Odesa } \\
\text { Kyiv }\end{array}$ \\
\hline
\end{tabular}




\section{Discussion of research results}

The obtained results of ranking the regions by groups (A, B, C and D) allow us to state the following. The largest number (15 regions of the country $-65.22 \%$ ) of the regions of Ukraine was part of group D, which is characterized by an extremely unfavorable state of development of the epidemiological situation. Group Afavorable condition included $4(17.39 \%)$ regions, and group B-relatively favorable condition of the epidemiological situation formed only 3 regions (13.04\%) (Fig. 1).

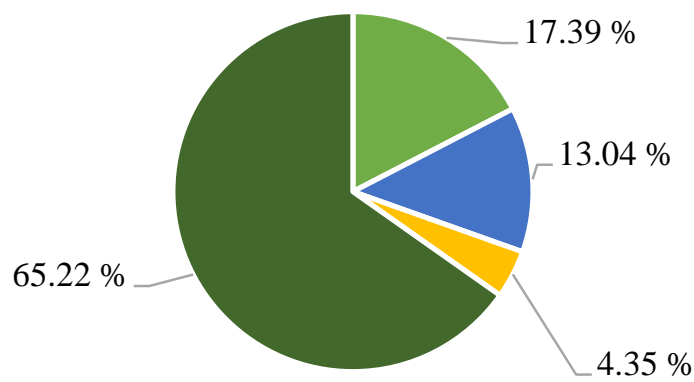

$$
\begin{aligned}
& \text { - Group A - favourable state } \\
& \text { - Group B - relatively favourable state } \\
& \text { - Group C - unfavourable state } \\
& \text { - Group D - extremely unfavorable state }
\end{aligned}
$$

Fig. 1. Analysis of the distribution of regions of Ukraine by groups in accordance with the state of development of the epidemiological process of GML

Interesting, in our opinion, is the fact that in this group there are different regions of the country, primarily industrial areas (Dnipropetrovsk, Zaporozhye, Kharkiv), as well as those that specialize in the development of rural production, primarily Sumy, Poltava, Rivne, Mykolayiv and so on. In addition, Group D includes regions representing different geographical areas of the country. Thus, the composition includes the western regions (Lviv, Rivne, Ternopil, Chernivtsi and others), southern (Odesa, Kirovograd, Mykolaiv), central (Kyiv, Poltava, Khmelnytsky, Sumy) and eastern administrativeterritorial units of the country (Dnipropetrovsk , Zaporizhia, Kharkiv).

It is noteworthy that despite the presence of the largest number (5) combinations, which are represented in group $\mathrm{C}$ - unfavourable state of the epidemiological situation for $\mathrm{LG}$, this group includes only 1 region (Ivano-Frankivsk). Group B - relatively favourable state of development of this process was represented by only 3 regions (Volyn, Cherkasy, Chernihiv regions).

Summarizing the results of the presented studies, it can be argued that most regions of the country are characterized by an unfavourable epidemiological situation regarding the development of LG and its treatment. We have proved that this situation is not related to the location of the region in the country, nor to the peculiarities of its development from a socioeconomic point of view.
Study limitations. Analyzing the presented results, we identified certain limitations in the study. First, in the calculations of the values of $\mathrm{X}_{\mathrm{av} \text {.morb. }}$ and $\mathrm{X}_{\mathrm{av} \text {.mort. for }}$ 2012-2018, updated epidemiological data were used, and for 2019 - operational. So, in NCR in the current year "operative" indicators of the account of oncological patients for the previous year are presented, and for other years all data have the status updated. In order to reduce the level of impact of operational indicators in 2019 in the calculations of $\mathrm{X}_{\mathrm{av} \text {.morb. and }} \mathrm{X}_{\mathrm{av} \text {.mort. we used data from }}$ 2012. The next limitation is due to the fact that in the calculations and ranking of regions by groups we did not use data from Donetsk, Luhansk, Crimea and Sevastopol. Thus, according to studies conducted in 2001, scientists have proved that the Autonomous Republic of Crimea and Donetsk region had rates of morbidity in the population of LG, which were higher than the average in Ukraine [34]. In addition, it is impossible to objectively assess the state of development of the onco-epidemiological situation in LG as a whole in Ukraine without taking into account the relevant indicators for the above-mentioned administrative-territorial units of the country.

Prospects for further research. The obtained research results allow us to assert the need for further analysis of the impact of various factors on the level of morbidity and mortality. This is especially true of such an important indicator, which is the 5-year survival of LG patients in different regions of the country. This is due to the presence of a significant number of regions (14 regions and the city of Kyiv) of Ukraine in the group D-extremely unfavourable state of development of the epidemiological situation with LG. Factor analysis will determine the factors that most influence the state of the onco-epidemiological situation, as well as the effectiveness of medical care and pharmaceutical support for LG patients in accordance with the peculiarities of regional development of individual administrativeterritorial units of the country.

\section{Conclusions}

LG is a pathology that requires considerable resources to treat patients for a long time. Therefore, the issues of prevention, early detection, organization of chemotherapy and further rehabilitation of patients should be considered in the area of rational distribution of limited funds of the health care system and society as a whole. Given the fact that Ukraine is currently in the process of decentralization of power, as well as effective models for improving the availability of medical and pharmaceutical services, the issue of rational allocation of resources aimed at providing cancer patients with anticancer drugs is important. The need to implement a regional approach in determining the needs of this group of oncohematological patients is due to significant fluctuations in $\mathrm{X}_{\mathrm{av} \text {.morb. }}$ and $\mathrm{X}_{\mathrm{av} \text {.mort. }}$ by regions of the country (from 1.8 to 3.0 and 0.4 to 0.9 , respectively, per 100 thousand population). The presented results form a reasonable basis for forecasting the amount of funding for the process of providing patients with LG with effective and affordable antitumor drugs.

\section{Conflict of interests}

The authors declare that they have no conflicts of interest. 


\section{References}

1. Khodamoradi, F., Pakzad, R., Ghoncheh, M., Gandomani, H. S., Salehiniya, H. (2018). Epidemiology, incidence and mortality of Hodgkin's cancer in the world and its relation with development. WCRJ, 5 (2), e1085.

2. Torre, L. A., Bray, F., Siegel, R. L., Ferlay, J., Lortet-Tieulent, J., \& Jemal, A. (2015). Global cancer statistics, 2012. CA: A Cancer Journal for Clinicians, 65 (2), 87-108. doi: http://doi.org/10.3322/caac.21262

3. Marri, P. R., Ansell, S. M. (2013). Progress in the initial management of Hodgkin's Lymphoma. Transfusion and Apheresis Science, 49 (1), 12-18. doi: http://doi.org/10.1016/j.transci.2013.05.018

4. Lin, J., Siegartel, L. R., Lingohr-Smith, M., Menges, B., Makenbaeva, D. (2017). Using Health Care Claims Data to Assess the Prevalence of Hodgkin Lymphoma and Relapsed or Refractory Hodgkin Lymphoma in the United States. Clinical Therapeutics, 39 (2), 303-310. doi: http://doi.org/10.1016/j.clinthera.2016.12.010

5. Gobbi, P. G., Ferreri, A. J. M., Ponzoni, M., Levis, A. (2013). Hodgkin lymphoma. Critical Reviews in Oncology/Hematology, 85 (2), 216-237. doi: http://doi.org/10.1016/j.critrevonc.2012.07.002

6. Eyre, T. A., King, A. J., Collins, G. P. (2013). Classical Hodgkin's lymphoma: past, present and future perspectives. British Journal of Hospital Medicine, 74 (11), 612-618. doi: http://doi.org/10.12968/hmed.2013.74.11.612

7. Vassilakopoulos, T. P., Angelopoulou, M. K. (2013). Advanced and Relapsed/Refractory Hodgkin Lymphoma: What Has Been Achieved During the Last 50 Years. Seminars in Hematology, 50 (1), 4-14. doi: http://doi.org/10.1053/j. seminhematol.2013.02.002

8. Salati, M., Cesaretti, M., Macchia, M., El Mistiri, M., Federico, M. (2014). Epidemiological Overview of Hodgkin Lymphoma Across the Mediterranean Basin. Mediterranean Journal of Hematology and Infectious Diseases, 6 (1), e2014048. doi: http://doi.org/10.4084/mjhid.2014.048

9. Khajedaluee, M., Dadgarmoghaddam, M., Saeedi, R., Izadi-Mood, Z., Abrishami, M., Zamani, M. (2014). Mortality, Morbidity, Survival, and Burden of Top 9 Cancers in a Developing Country. Razavi International Journal of Medicine, 2 (3). doi: http://doi.org/10.5812/rijm.20073

10. Ansell, S. M. (2016). Hodgkin lymphoma: 2016 update on diagnosis, risk-stratification, and management. American Journal of Hematology, 91 (4), 434-442. doi: http://doi.org/10.1002/ajh.24272

11. Siegel, R. L., Miller, K. D., Jemal, A. (2020). Cancer statistics, 2020. CA: A Cancer Journal for Clinicians, 70 (1), 7-30. doi: http://doi.org/10.3322/caac.21590

12. Smith, E. C., Ziogas, A., Anton-Culver, H. (2012). Association between insurance and socioeconomic status and risk of advanced stage Hodgkin lymphoma in adolescents and young adults. Cancer, 118 (24), 6179-6187. doi: http://doi.org/ $10.1002 /$ cncr. 27684

13. Sullivan, R., Kowalczyk, J. R., Agarwal, B., Ladenstein, R., Fitzgerald, E., Barr, R. et. al. (2013). New policies to address the global burden of childhood cancers. The Lancet Oncology, 14 (3), e125-e135. doi: http://doi.org/10.1016/s1470-2045(13)70007-x

14. Houweling, T. A. J., Kunst, A. E. (2009). Socio-economic inequalities in childhood mortality in low- and middle-income countries: a review of the international evidence. British Medical Bulletin, 93 (1), 7-26. doi: http://doi.org/10.1093/bmb/ldp048

15. Ansell, S. M. (2020). Hodgkin lymphoma: A 2020 update on diagnosis, risk- stratification, and management. American Journal of Hematology, 95 (8), 978-989. doi: http://doi.org/10.1002/ajh.25856

16. Macalalad, A. R., McAuliffe, M., Yang, H., Kageleiry, A., Zhong, Y., Wu, E. Q. et. al. (2015). The epidemiology and targeted therapies for relapsed and refractory CD30+ lymphomas. Current Medical Research and Opinion, 31 (3), 537-545. doi: http://doi.org/10.1185/03007995.2015.1008131

17. Szabo, S. M., Hirji, I., Johnston, K. M., Juarez-Garcia, A., Connors, J. M. (2017). Treatment patterns and costs of care for patients with relapsed and refractory Hodgkin lymphoma treated with brentuximab vedotin in the United States: A retrospective cohort study. PLOS ONE, 12 (10), e0180261. doi: http://doi.org/10.1371/journal.pone.0180261

18. Mahdavifar, N., Ghoncheh, M., Pakzad, R., Momenimovahed, Z., Salehiniya, H. (2016). Epidemiology, Incidence and Mortality of Bladder Cancer and their Relationship with the Development Index in the World. Asian Pacific Journal of Cancer Prevention, 17 (1), 381-386. doi: http://doi.org/10.7314/apjcp.2016.17.1.381

19. Ferlay, J., Steliarova-Foucher, E., Lortet-Tieulent, J., Rosso, S., Coebergh, J. W. W., Comber, H. et. al. (2013). Cancer incidence and mortality patterns in Europe: Estimates for 40 countries in 2012. European Journal of Cancer, 49 (6), 1374-1403. doi: http://doi.org/10.1016/j.ejca.2012.12.027

20. Abramson, J. S., Arnason, J. E., LaCasce, A. S., Redd, R., Barnes, J. A., Sokol, L. et. al. (2019). Brentuximab vedotin, doxorubicin, vinblastine, and dacarbazine for nonbulky limited-stage classical Hodgkin lymphoma. Blood, 134 (7), 606-613. doi: http://doi.org/10.1182/blood.2019001272

21. Connors, J. M., Jurczak, W., Straus, D. J., Ansell, S. M., Kim, W. S., Gallamini, A. et. al. (2018). Brentuximab Vedotin with Chemotherapy for Stage III or IV Hodgkin's Lymphoma. New England Journal of Medicine, 378 (4), 331-344. doi: http://doi.org/10.1056/nejmoa1708984

22. Bröckelmann, P. J., Goergen, H., Keller, U., Meissner, J., Ordemann, R., Halbsguth, T. V. et. al. (2019). Nivolumab and AVD for Early-Stage Unfavorable Hodgkin Lymphoma (NIVAHL). Blood, 134 (1), 236. doi: http://doi.org/10.1182/blood-2019122406

23. Ramchandren, R., Domingo-Domènech, E., Rueda, A., Trněný, M., Feldman, T. A., Lee, H. J. et. al. (2019). Nivolumab for Newly Diagnosed Advanced-Stage Classic Hodgkin Lymphoma: Safety and Efficacy in the Phase II CheckMate 205 Study. Journal of Clinical Oncology, 37 (23), 1997-2007. doi: http://doi.org/10.1200/jco.19.00315

24. De Angelis, R., Sant, M., Coleman, M. P., Francisci, S., Baili, P., Pierannunzio, D. et. al. (2014). Cancer survival in Europe 1999-2007 by country and age: results of EUROCARE-5 - a population-based study. The Lancet Oncology, 15 (1), 23-34. doi: http://doi.org/10.1016/s1470-2045(13)70546-1

25. Tit, A., Martin-Moreno, J. M., Jelenc, M., Gorgojo, L., Harris, M. (Eds.) (2015). European Guide for Quality National Cancer Control Programme. National Institute of Public Health. Ljubljana, 113.

26. National Cancer Registry of Ukraine: short description of the database as of January, 2020. Cancer in Ukraine 2018 2019. Available at: https://unci.org.ua/spetsialistam/nacionalnij-kancer-reyestr/

27. Verkhovna Rada Ukrainy. Ofitsiinyi veb-portal. Administratyvno-terytorialnyi ustrii. Available at: http://static.rada.gov.ua/zakon/new/NEWSAIT/ADM/zmist.html

28. Fang, J.-Q. (Ed.) (2017). Handbook of Medical Statistics. World Scientific, 850. 
29. Yasenchak, C. A., Tseng, W.-Y., Yap, M., Rembert, D., Patt, D. A. (2015). Economic impact of disease progression following front-line therapy in classical Hodgkin lymphoma. Leukemia \& Lymphoma, 56 (11), 3143-3149. doi: http://doi.org/10.3109/10428194.2015. 1030639

30. National Comprehensive Cancer Network. NCCN Clinical Practice Guideline in Oncology (NCCN Guidelines): Hodgkin lymphoma (2013). Available at: https://www2.tri-kobe.org/nccn/guideline/hematologic/english/hodgkins.pdf

31. Kushchevyi, Ye. V., Kriachok, I. A., Martynchyk, A. V., Filonenko, K. S. (2001). Likuvannia patsiientiv z retsydyvamy ta refrakternym perebihom limfomy Khodzhkina. Rol vysokodozovoi khimioterapii ta transplantatsii hemopoetychnykh stovburovykh klityn. Klinichna onkolohiia, 1 (1), 78-88.

32. Sivkovych, S. O., Mnishenko, V. M., Kaliuta, A. O. (2014). Limfoma Khodzhkina: suchasni aspekty diahnostyky ta likuvannia. Zbirnyk naukovykh prats spivrobitnykiv NMAPO imeni P. L. Shupyka, 23 (3), 667-674.

33. Eyre, T. A., King, A. J., Collins, G. P. (2013). Classical Hodgkin's lymphoma: past, present and future perspectives. British Journal of Hospital Medicine, 74 (11), 612-618. doi: http://doi.org/10.12968/hmed.2013.74.11.612

34. Krivets, D. Ia. (2001). Epidemiologiia limfogranulematoza v Ukraine v 1991-1998 gg. Onkologiia, 3 (1), 11-15.

Received date 17.11.2020

Accepted date 22.12.2020

Published date 30.12.2020

Hanna Panfilova, Doctor of Pharmaceutical Sciences, Professor, Department of Organization and Economics of Pharmacy, National University of Pharmacy, Pushkinska str., 53, Kharkiv, Ukraine, 61002

E-mail: panf-al@ukr.net

Marta Matushchak, Assistant, Department of Pharmaceutical Botany and Pharmacognosy, Higher State Educational Institution of Ukraine «Bukovinian State Medical, University», Teatralna sq., 2, Chernivtsi, Ukraine, 58002

E-mail: matushakmarta@gmail.com

Liliia Kostyshyn, Assistant, Department of Pharmaceutical Botany and Pharmacognosy, Higher State Educational Institution of Ukraine «Bukovinian State Medical, University», Teatralna sq., 2, Chernivtsi, Ukraine, 58002

E-mail: lilia.kostyshyn92@gmail.com

Olha Skrynchuk, Assistant, Department of Pharmacy, Higher State Educational Institution of Ukraine «Bukovinian State Medical, University», Teatralna sq., 2, Chernivtsi, Ukraine, 58002

E-mail: olichka0807olichka@gmail.com

Zyro Dominik,.Department of Bioinorganic Chemistry, Chair of Medicinal Chemistry, Medical University of Lodz, Pl. Hallera 1, 90-647, Lodz, Poland

E-mail: dominik.zyro@umed.lodz.pl

Oksana Tsurikova, PhD, Assistant. Department of Management, Economics and Quality Assurance in Pharmacy, National University of Pharmacy, Pushkinska str., 53, Kharkiv, Ukraine, 61002

E-mail: zurikova2008@gmail.com 